\begin{tabular}{l}
\hline Nuansa Journal of Arts and Design \\
Volume 4 Nomor 2 September 2020 \\
e-ISSN: 2597-405X dan p-ISSN: $2597-4041$ \\
\begin{tabular}{|l|l|}
\hline (1) This work is licensed under a Creative Commons Attribution \\
4.0 International License
\end{tabular} \\
\hline
\end{tabular}

\title{
PEMBUATAN BATIK DI FAKULTAS SENI DAN DESAIN UNIVERSITAS NEGERI MAKASSAR
}

\section{Aulia Evawani Nurdin}

\section{Corespondensi Author}

Prodi Pendidikan Seni Rupa Fakultas Seni dan Desain Universitas Negeri Makassar

Email:

auliaevawani@unm.ac.id

\begin{abstract}
ABSTRAK
Penelitian ini bertujuan untuk untuk memperoleh data yang jelas dan akurat mengenai proses pembuatan batik di Fakultas Seni dan Desain Universitas Negeri Makassar. Jenis penelitian ini merupakan penelitian kualitatif. Teknik pengumpulan data dilakukan dengan teknik observasi, wawancara, dokumentasi dan kepustakaan. Analisis data dilakukan dengan teknik analisis deskriptif kualitatif. Hasil penelitian ini menunjukkan bahwa proses pembuatan batik yang menerapkan motif Toraja, alam dan kaligrafi. Pembuatan batik tersebut menggunakan teknik tulis dan teknik colet dengan bahan pewarna napthol. Dalam proses pembuatan batik tersebut diperlukan kecermatan dan kehati-hatian untuk menghasilkan karya batik yang lebih berkualitas. Hasil penerapan tersebut meupakan wujud pelestarian budaya lokal sehingga menambah kekayaan budaya Indonesia.
\end{abstract}

Kata Kunci: Batik, Tulis, Colet.

\section{PENDAHULUAN}

Kebudayaan Indonesia sangat beragam tersebar di wilayah Nusantara dengan karakteristik yang beragam pula sesuai dengan kebudayaan daerah masing-masing. Kebudayaan daerah merupakan pendukung dalam menambah khasanah budaya nasional, namun keanekaragaman budaya ini diperkuat dengan budaya etnik yang ada di wilayah itu. Untuk memperkuat kebudayaan bangsa Indonesia dapat dilakukan dengan menggali potensi dan memupuk kesenian daerah yang ada.

Batik merupakan salah satu unsur seni budaya bangsa Indonesia yang masih bertahan dan mengalami perkembangan yang sangat pesat dewasa ini. Bahkan tak hanya merupakan konsumsi masyarakat Indonesia sendiri tetapi juga masyarakat mancanegara. Pada tanggal 2 Oktober 2009, batik Indonesia telah dikukuhkan sebagai warisan budaya dunia oleh Badan Internasional PBB, United Nations Education, Scientific, and Culture Organization (UNESCO).

Batik telah menjadi milik bangsa Indonesia, yang semula hanya berpusat di Jawa dan kini telah tersebar di berbagai wilayah di Indonesia dengan ciri khas masing-masing daerah. Indonesia telah memiliki beragam batik dengan beragam motif batik yang indentik dengan ciri khas daerah pembuatan batik tersebut, antara lain: Pekalongan terkenal dengan batik Pekalongan, Kalimantan Timur dengan batik 
batang garing, Toraja dengan batik Toraja dan beragam jenis batik lainnya.

Batik adalah seni dan cara, untuk menghias suatu kain dengan menggunakan penutup lilin atau malam untuk membentuk corak dan pola hiasnya, membentuk bidang pewarnaan, sedang warnanya itu sendiri dicelup dengan menahan zat warna (Satmawi, 1979: 12). Bila ditinjau dari teknik pembuatannya, maka terdapat dua macam batik yaitu batik tulis dan batik cap. Batik tulis adalah batik yang dihasilkan dengan cara menggunakan canting tulis sebagai alat bantu untuk melekatkan cairan malam (lilin) pada kain. Sedangkan batik cap adalah batik yang diproses menggunakan canting cap menggantikan canting tulis dalam menerapkan cairan malam pada kain.

Dalam kerangka pelestarian budaya bangsa, batik selama ini telah menunjukkan eksistensinya dalam kehidupan sehari-hari masyarakat Indonesia, dengan berbagai motif dan ragam batik yang tumbuh seiring dengan ciri khas setiap daerah yang mengembangkannya. Upaya pengembangan batik yang dilakukan di berbagai daerah untuk dijadikan sebagai komoditas perdagangan, pada gilirannya melahirkan nama jenis batik yang diproduksinya berdasarkan ciri khas motif dan nama daerah yang bersangkutan, seperti batik Yogyakarta, Solo, Pekalongan, Lasem, Cirebon, Tegal, Madura dan Papua.

Di Sulawesi Selatan batik sudah cukup dikenal, namun masih sedikit yang dapat menerangkan proses pembuatannya sehingga perkembangan pembuatan batik di masyarakat Sulawesi Selatan masih dikatakan sangat sedikit, sebab minat masyarakat untuk dapat mempelajari proses pembuatan batik itu sendiri sangat kurang, padahal apabila masyarakat Sulawesi Selatan ingin mengembangkan batik di provinsi ini maka tidak menutup kemungkinan dapat mengangkat unsur-unsur budaya yang ada di daerah ini melalui penerapaan motif khas daerah pada kain.

Saat ini pengetahuan dan keterampilan batik telah diajarkan pada Pendidikan Dasar,
Pendidikan Menengah hingga Pendidikan Tinggi yang memiliki program studi pendidikan seni rupa/seni rupa sebagai upaya dalam pelestarian budaya batik. Fakultas Seni dan Desain merupakan fakultas di Universitas Negeri Makassar yang mengajarkan proses pembuatan batik secara langsung kepada mahasiswa.

Berdasarkan uraian tersebut maka penulis bermaksud untuk mengadakan penelitian dengan mengangkat judul pembuatan di Fakultas Seni dan Desain Universitas Negeri Makassar. Penelitian ini bertujuan untuk memperoleh data yang jelas dan akurat mengenai proses pelestarian batik di Fakultas Seni dan Desain Universitas Negeri Makassar.

Batik adalah kain tekstil hasil pewarnaan, pencelupan rintang menurut corak khas ciri batik Indonesia, dengan menggunakan lilin batik sebagai zat perintang. Batik menurut Satmawi (1979: 12), adalah seni dan cara, untuk menghias suatu kain dengan menggunakan penutup lilin atau malam untuk membentuk corak dan pola hiasnya, membentuk bidang pewarnaan, sedang warnanya itu sendiri dicelup dengan menahan zat warna. Sedangkan menurut Hamzuri (1981: 1), batik adalah lukisan atau gambar pada mori yang dibuat dengan menggunakan alat bernama canting. Menurut Sofyan Salam (2000: 87), batik adalah proses pewarnaan pada tekstil dengan cara menggunakan lilin untuk menutupi area yang diinginkan untuk tidak dikenai warna. Dalam Phinisi (Jurnal Pendidikan Bahasa dan Seni) yang dikemukakan oleh Drs. A. Mattaropura Husain (1992: 69), proses pembuatan batik adalah proses tutup celup. Pengertian tutup celup yaitu bagian-bagian kain ditutup dengan bahan penutup (sejenis lilin) dan mencelupkannya ke dalam warna. Setelah dikemukakan pengertian batik dari beberapa pendapat para tokoh maka dapat ditarik kesimpulan bahwa batik ialah seni menghias dan mewarnai kain yang menggunakan teknik tutup celup. 


\section{METODE PENELITIAN}

Sifat penelitian yaitu penelitian lapangan dan penelitian kepustakaan, maka teknik yang dipergunakan untuk memperoleh data penelitian yaitu Teknik penelitian kepustakaan dilakukan dengan cara mengkaji sejumlah buku-buku dan literatur yang relevan dengan objek yang diteliti. Dalam pelaksanaan penelitian ini, pendapatpendapat yang diperoleh melalui literatur akan dibahas dan disesuaikan dengan data yang diperoleh dari lapangan. Teknik penelitian lapangan dilakukan dengan menempuh beberapa langkah yaitu: Teknik Observasi adalah pengumpulan data yang mengamati secara langsung kegiatan ini, mulai dari persiapan pengolahan bahan hingga akhir atau selesai. Teknik Dokumentasi dilakukan peneliti untuk mengumpulkan data dengan cara mengambil data dan mendokumentasikan data yang berkaitan dengan masalah yang diteliti. Untuk kelengkapan data, dilakukan pula wawancara dengan dosen yang bersangkutan. Data yang diperoleh kemudian disusun dan diklasifikasikan serta dianalisis secara deskriptif kualitatif. Hal ini dimaksudkan untuk memperoleh gambaran yang dapat dipenuhi secara jelas dan terarah yang berkaitan dengan pembuatan batik.

\section{HASIL PENELITIAN DAN PEMBAHASAN}

Seni Batik mulai diperkenalkan pada Jurusan Seni Rupa IKIP Ujung Pandang pada tahun 1976 yang pertama kali yang mengajarkan ialah (alm) Drs. Nurdin Kallo, diajarkan sebagai bagian dari kurikulum. Dalam silabi Bidang Studi Seni Rupa FKSS IKIP Ujung Pandang tahun 1979 seni batik dipelajari dalam mata kuliah seni lukis IV. Teknik yang diajarkan yaitu penggunaan canting pada saat membuat batik dan teknik celup. Kemudian menghasilkan gambargambar yang dekoratif.

Tahun 1982 Drs. Nurdin Kallo didampingi oleh Drs. A. Mattaropura Husain. Ketika itu. Drs. A. Mattaropura Husain melakukan perkuliahan (praktek) di rumahnya sendiri berhubung keterbatasan tempat. Melihat kondisi tersebut, beberapa tahun kemudian akhirnya pihak fakultas memberikan ruangan khusus untuk praktek seni lukis batik yang kini dikenal dengan sebutan studio batik. Studio batik saat ini di bawah naungan Fakultas Seni dan Desain Universitas Negeri Makassar. Studio tersebut digunakan untuk perkuliahan batik/kriya tekstil/kriya bahan sintetik dan studi khusus batik dengan dosen pengampu mata kuliah Hasnawati, S.Pd., M.Pd. Dalam pengajarannya, beliau masih menerapkan cara-cara pewarnaan yang lebih efektif dan menghasilkan warna-warna yang cemerlang dan gambar yang dihasilkan masih bersifat dekoratif.

Proses pembuatan batik di Fakultas Seni dan Desain Universitas Negeri Makassar sebagai berikut:

\section{a. Persiapan alat dan bahan}

Alat yang dipergunakan dalam pembuatan batik di Fakultas Seni dan Desain Universitas Negeri Makassar adalah sebagai berikut:

1) Wajan, berfungsi sebagai tempat untuk mencairkan lilin atau malam.

2) Kompor minyak tanah ukuran kecil, berfungsi untuk memanaskan wajan agar lilin (malam) di dalam wajan mencair.

3) Canting, berfungsi untuk membuat motif batik pada kain. Jenis canting terdiri dari canting tulis. Canting tulis terbuat dari tembaga mempunyai sifat ringan. Canting tulis terdiri dari cucuk (saluran kecil) dan leleh (tangki).

4) Kuas bambu, berfungsi untuk menutup bidang yang lebar pada kain. Digunakan pada proses pelilinan.

5) Kuas colet berfungsi menyapukan pewarna pada motif dengan teknik colet.

6) Gawangan, berfungsi untuk membentangkan kain agar mudah dibalik. Alat ini terbuat dari kayu dan mudah dipindah-pindahkan karena sifatnya yang ringan.

7) Besi, berfungsi untuk melepaskan lilin, jika terjadi kesalahan tempat penerapan lilin.

8) Cerek, berfungsi sebagai wadah memanaskan air.

9) Timbangan, berfungsi untuk menimbang bahan pewarna yang digunakan dalam pewarnaan. 
10) Gelas ukur, berfungsi untuk mengukur banyaknya air yang akan digunakan dalam proses pelarutan napthol dan garam.

11) Baskom, berfungsi sebagai wadah atau tempat untuk melarutkan napthol dan garam, juga sebagai tempat dalam proses pewarnaan.

12) Sendok, sebagai alat yang digunakan untuk mengambil bahan pewarna dan mencampur bahan pewarna.

13) Meja pewarnaan, berfungsi sebagai tempat dalam proses pewarnaan.

14) Kuas, berfungsi untuk menguaskan pewarna pada bagian-bagian tertentu yang diinginkan dengan teknik sembur.

15) Jemuran, alat tersebut terbuat dari batangan bambu yang telah diberi paku yang berfungsi untuk menggantung kain yang telah dicelup dalam larutan napthol dan garam (bahan pembangkit warna).

16) Kipas Angin untuk mempercepat proses pengeringan karya.

Adapun alat yang digunakan dalam proses pelepasan lilin dari kain (melorod) sebagai berikut:

1) Kompor gas ukuran besar, berfungsi untuk memanaskan air dalam panci.

2) Panci, berfungsi sebagai tempat untuk memasak kain, agar lilinnya keluar atau lepas dari kain (melorod).

3) Pengaduk, berfungsi untuk mengaduk kain yang berada di dalam panci, agar kain tidak melengket pada dasar panci atau hangus.

4) serok, berfungsi untuk mengambil lilin yang berada dalam panci.

5) Baskom, berfungsi sebagai tempat melarutkan kanji dengan air dan sebagai wadah pencucian kain setelah dimasak.

6) Sendok, berfungsi untuk mengaduk larutan kanji.

Jenis bahan yang digunakan dalam proses pembuatan batik Fakultas Seni dan Desain Universitas Negeri Makassar adalah sebagai berikut:

1) Kain merupakan bahan baku utama dalam pembuatan batik (pembatikan). Kain yang digunakan ialah kain katun.

2) Lilin (malam), berfungsi untuk menutup bagian-bagian pola atau motif agar tidak terkena pewarna pada waktu pewarnaan. Jenis lilin yang biasanya digunakan ialah lilin tembokan.
3) Zat pewarna Napthol. Penggunaan warna Napthol dengan bahan pembangkit warnanya adalah garam diazonium (biasanya disebut garam) serta selalu menggunakan bahan pencampur Caustic soda (Soda Api).

4) Garam Diazonium, bahan ini digunakan sebagai bahan pembangkit pewarna Napthol.

5) Caustic soda atau Soda Api, bahan ini digunakan untuk melarutkan napthol.

6) Turkis Red Oil (TRO), berfungsi sebagai obat pembasah untuk mencuci kain yang akan dicap atau dinapthol.

7) Sabun mandi, digunakan untuk mencuci kain yang sudah terbebaskan dari lilin. Bahan ini digunakan pada saat proses melorod.

8) Kanji, digunakan untuk melepaskan lilin dari kain ketika dimasak (melorod).

\section{b. Tahap-Tahap Pembuatan Batik}

1) Pembuatan desain atau pola

Pembuatan desain dilakukan juga dengan cara terlebih dahulu dibuat di atas kertas HVS sesuai dengan motif yang diinginkan dengan menggunakan pensil. Setelah gambar tersebut selesai dibuat, kemudian dipindahkan pada kertas gambar dengan menyesuaikan panjang kain yang akan dibatik, kemudian diperjelas dengan menggunakan pulpen.

2) Pemindahan pola (desain)

Sebelum pola motif dipindahkan di atas kain terlebih dahulu kain dicuci dengan menggunakan TRO, atau sabun agar kotoran dan kanji yang terdapat pada kain tersebut keluar. Kemudian pola disusun sedemikian rupa di bawah kain. Lalu menyalin atau memindahkan pola dapat dilakukan dengan menggunakan pensil dengan mengikuti motif pada pola tersebut. Pekerjaan ini harus dilakukan dengan hati-hati dan teliti agar kain tidak bergeser atau motif tidak meleset. Setelah pola atau desain motif batik tersebut sudah dipindahkan maka kain ini siap untuk dililin. Kain yang telah dipotong dan dipola sebelum dililin terlebih dahulu pada setiap sudut kain yang akan dililin diberi benang atau tali sebagai gantungan untuk memudahkan digantung pada proses pewarnaan.

3) Pembuatan warna

Proses pewarnaan motif pada batik di Fakultas Seni dan Desain Universitas Negeri Makassar menggunakan dua jenis pewarna, yaitu pewarna Napthol. Zat pewarna napthol 
sudah biasa dipakai dalam pembatikan. Warnawarna napthol terdiri dari komponen napthol sebagai komponen dasar dan komponen pembangkit warna, yaitu garam diazonium atau disebut garam. Perbandingan pemakaian napthol dan garam antara $1: 2$ sampai $1: 3$. Dalam melarutkan napthol digunakan caustic soda (soda api) yang pemakaiannya antara setengah sampai satu kali berat napthol.

Adapun langkah-langkah yang ditempuh pada proses pewarnaan dengan menggunakan napthol adalah sebagai berikut: Terlebih dahulu kain (yang akan dicelup warna) dicelupkan di dalam larutan TRO. Mempersiapkan alat dan bahan pewarna napthol sesuai dengan desain motif batik yang akan diterapkan, dengan rumus bahan pewarna yang telah direncanakan. Timbang bahan sesuai dengan rumus bahan pewarna yang telah direncanakan. Panaskan air hingga mendidih, lalu masukkan air pada pewarna napthol.

Mempersiapkan larutan garam Diazonium. Garam tersebut dicampur dengan sedikit air, lalu diaduk rata hingga menjadi pasta. Kemudian tambahkan air bersih ke dalam baskom, lalu diaduk rata hingga tercampur dengan baik, sehingga menjadi larutan garam yang siap dipergunakan.

4) Proses Pencoletan

Pencoletan dilakukan dengan cara menyapukan kuas yang terbuat dari lidi dan kapas yang telah diberi pewarna napthol pada kain. Kemudian kain didiamkan beberapa menit hingga lembab, lalu bagian yang telah terkena pewarna napthol, diberikan pembangkit warna berupa garam dizonium dengan cara dicolet. Dalam pencoletan pewarna sebaiknya menggunakan kuas yang berbeda pada setiap pewarna agar hasil warna yang dihasilkan bersih atau sesuai dengan yang diinginkan.

5) Proses Pelilinan (Pelekatan lilin pada kain) dengan menggunakan canting tulis. Menyediakan alat (kompor minyak tanah ukuran kecil, wajan, canting, kuas bambu, gawangan dan kain bekas) dan bahan (lilin/malam). Nyalakan api pada kompor, lalu panaskan lilin/malam yang berada di dalam wajan di atas kompor tersebut sampai semua lilin meleleh, lilin tidak boleh terlalu panas karena dapat menyebabkan lilin menjadi hangus dan hasil pelilinan juga tidak bagus (keluar dari pola/motif). Kain yang akan dibatik disampirkan di atas gawangan di depan pembatik.
Pembatik mengambil lilin batik cair dengan canting tulis, lalu diangkat, kemudian ujung canting dihembus (secara perlahan) dan mulailah menorehkan lilin pada kain (membatik). Apabila terdapat lilin batik salah tempel karena tetesan, tetesan tersebut dapat dihilangkan dengan cara, kain bagian yang salah (tetesan lilin) dibasahi dengan larutan kanji dan dikerok menggunakan besi panas.

6) Proses Pewarnaan

Larutan napthol disiramkan ke seluruh permukaan kain di dalam wadah pencelupan warna. Cairan larutan tersebut dikuas secara berulang ke seluruh permukaan kain secara merata, agar cairan larutan tersebut menyerap merata ke serat kain. Atau dapat juga dilakukan dengan cara mencelupkan kain di dalam baskom plastik, lalu mengucek secara perlahan, namun perlakuan ini memiliki resiko yaitu lilin (malam) yang melekat pada kain dapat menjadi retak atau runtuh sehingga cairan warna akan terserap ke dalam serat dari bagian kain yang tidak diinginkan. Setelah melakukan pewarnaan pada kain, maka kain diangkat dan diangin-anginkan (diatuskan) pada jemuran.

Kemudian disapukan (disiram) larutan garam tersebut ke permukaan kain secara merata. Kemudian kain dicuci (disiram) dengan air bersih, lalu diangkat dan dikeringkan, dengan cara digantung vertikal pada jemuran. Untuk pewarnaan II, III dan seterusnya, tahapan proses tersebut dilakukan dengan cara yang sama.

7) Pelilinan (pemberian malam atau lilin pada kain) pada bagian-bagian tertentu dari motif yang diterapkan dilakukan untuk menghasilkan warna tertentu yang diinginkan dengan menutup bagian-bagian lainnya. Pelilinan dapat dilakukan dengan menggunakan cap batik (canting cap), canting tulis dan kuas, pada setiap kali sebelum melakukan pencelupan warna.

8) Pelorodan, yaitu melepaskan lilin atau malam dari kain. Hal ini merupakan suatu tahapan akhir dalam rangkaian proses pembatikan.

Alat dan bahan yang digunakan dalam proses pelorodan adalah kompor, minyak tanah, panci untuk memasak, pengaduk, penyaring, baskom plastik, air, kanji dan sabun mandi (sabun bersoda rendah). Adapun tahapan pelorodan adalah sebagai berikut: Memasak air di dalam panci sampai mendidih (suhu $100^{\circ} \mathrm{C}$ ). Membuat larutan kanji (1 liter air +10 gram kanji), lalu masukkan kanji tersebut ke dalam panci yang berisi air mendidih sambil diaduk secara perlahan. Setelah air kembali mendidih, 
Pembuatan Batik Di Fakultas Seni Dan Desain Universitas Negeri Makassar

masukkan kain yang akan dilorod ke dalam panci sambil diaduk secara perlahan dan sesekali kain tersebut diangkat secara bergantian dengan menggunakan pengaduk. Angkat lilin-lilin yang terlepas dari kain (lilin akan mengapung pada permukaan air) dengan menggunakan serok.

Ketika kain sudah diperkirakan terbebaskan dari lilin, kain siap untuk diangkat (dikeluarkan dari panci) dan langsung dimasukkan kedalam baskom yang sudah terisi air, segerelah mengucek kain agar lilin tidak melekat kembali pada kain. Lakukan pencucian ini hingga kain sudah terbebaskan dari lilin. Lalu cuci kain dengan sabun, tetapi dalam penggunaan sabun tersebut jangan terlalu banyak agar warna pada kain batik tidak pudar (luntur). Setelah itu, bilas kain sampai bersih. Setelah kain bersih, segera angkat dan jemur hingga kering.
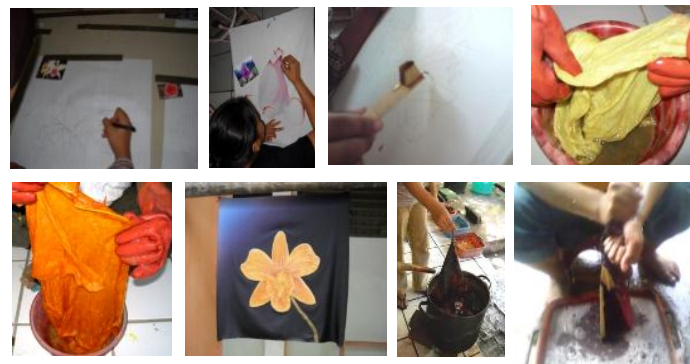

Gambar 1

Proses Pembuatan Batik

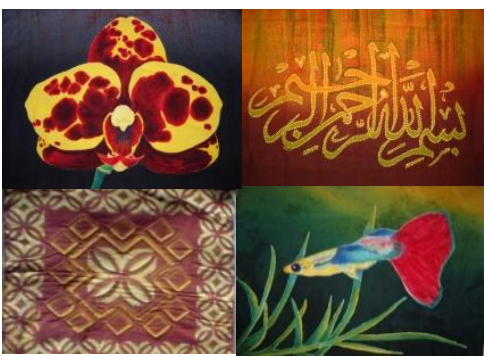

Gambar 2

Hasil Akhir Karya Bati

\section{KESIMPULAN DAN SARAN}

a. Kesimpulan

Pembuatan batik Fakultas Seni dan Desain Universitas Negeri Makassar melalui pembuatan batik menggunakan bahan (zat) pewarna Napthol, menggunakan lilin tembokan serta kain katun. Penorehan lilin pada kain menggunakan canting tulis dan kuas. Teknik yang digunakan dalam pembuatan batik ialah teknik tulis dan colet. Dalam pembuatan batik, membutuhkan kecermatan dan ketelitian. Dengan kata lain, proses pelilinan, pewarnaan, serta proses pengerjaannya harus dilakukan secara cermat dan selektif.

\section{b. Saran}

Diharapkan kepada instansi-instansi yang terkait agar dapat membantu dalam memperkenalkan batik kepada masyarakat luas. Diharapkan kepada pemerintah dan masyarakat agar di Makassar terdapat toko yang menjual alat dan bahan untuk membatik. Diharapkan lebih banyak lagi yang menerapkan motif khas daerah atau bahkan motif khas Sulawesi Selatan pada praktek pembatikan (batik).

\section{DAFTAR PUSTAKA}

Azis Said, dkk. 2009. Pengembangan Produk Akhir Kain Tenun Sutera Berbasis Budaya Lokal, (Laporan Hasil Penelitian Strategi Nasional), DIPA Universitas Negeri Makassar.

Hamzuri. 1981. Batik Klasik. Jakarta : Djambatan.

Husain, A. Mattaropura. 1992. Pengembangan Mata Kuliah Kerajinan Batik Pada Jurusan Seni Rupa FPBS IKIP Ujung Pandang. Pinisi Jurnal Pendidikan Bahasa dan Seni, Volume I No. 2 Februari 1992, Fakultas Pendidikan Bahasa dan Seni IKIP Ujung Pandang.

Husain, Muhammad Saleh. 2001. Tesis : Ragam Hias sebagai Media Komunikasi Simbolik dalam Struktur Masyarakat Toraja.

Kawindrosusanto, Kuswadji. 1977.Unsur Tradisional Dalam Seni Lukis Batik Kontemporer. Jakarta.

Muhfi, Muhammad. 2009. Tiang Penyangga. Online. http://halaman putih.wordpress.com/tag/kemben/.

Diakses 28 Desember 2010.

Rachman, Roslina. 2006. Skripsi: Pengembangan Teknik Seni Lukis Batik 
(studi khusus) di jurusan Seni Rupa Fakulstas Seni dan Desain Universitas Negeri Makassar.

Salam, Sofyan. 2000. Seni Rupa Mimesis dan Modern/Kontemporer di Sulawesi Selatan:Dewan Sulawesi Selatan.

Satmowi. 1979. Teknik Ikat dan Celup : BP. Pembimbing Putera.

Sewan Soesanto S. Teks, S.K..1980. Seni Kerajinan Batik Indonesia, Balai Penelitian Batik dan Kerajinan Lembaga Penelitian dan Pendidikan Industri Departemen Perindustrian R.I., Yogyakarta.

1984. Seni dan

Teknologi Kerajinan Batik, Departemen Pendidikan dan Kebudayaan, Jakarta.

Wulandari, Ari. 2011. Batik Nusantara. CV. Andi Offset. Yogyakarta. 